\title{
PELATIHAN PRAKTIKUM SEDERHANA BAGI GURU-GURU IPA SMP DI KECAMATAN MOLLO UTARA KABUPATEN TIMOR TENGAH SELATAN
}

\author{
Getrudis Wilhelmina Nau ${ }^{1 *}$, Hildegardis Missa ${ }^{1}$ \\ ${ }^{1}$ Program Studi Pendidikan Biologi, Fakultas Keguruan dan Ilmu Pendidikan, Universitas Katolik Widya Mandira, \\ Kupang, Indonesia \\ *Penulis korespondensi: aureliarenata26@gmail.com
}

\begin{abstract}
Abstrak
Pembelajaran kini harus mampu mendorong siswa untuk dapat bertindak sebagai saintis terutama pembelajaran sains. Hal ini berarti pembelajaran harus berbasis pada praktikum. Namun, Guru-guru IPA di beberapa SMP se-Kecamatan Mollo Utara, Kabupaten Timor Tengah Selatan memiliki permasalahan yaitu guru belum memahami hakekat pembelajaran sains, pentingnya praktikum dalam pembelajaran IPA, kurangnya kreativitas guru dalam merancang praktikum IPA sederhana dan tidak adanya modul praktikum. Solusi yang dapat dilakukan untuk mengatasi permasalahan-permasalahan tersebut adalah dengan melakukan pelatihan praktikum sederhana bagi guru-guru IPA SMP seKecamatan Mollo Utara, Kabupaten Timor Tengah Selatan. Metode yang dilakukan adalah pemaparan materi tentang hakekat sains, pentingnya praktikum dalam pembelajaran, cara merancang praktikum sederhana serta cara membuat modul praktikum; penayangan video berbagai praktikum sains dengan alat dan bahan sederhana yang mudah ditemui di lingkungan sekitar; dan demostrasi beberapa praktikum sederhana.
\end{abstract}

Kata kunci: pembelajaran sains; saintis; praktikum sederhana

\begin{abstract}
The current learning must be able to encourage student to become scientists especially science learning. This means that learning must be based on practicum. However, science teacher in several junior high school in Mollo Utara sub-district, South Central Timor have any problem; the teacher does not understand the nature of science learning, the importance of practicum in science learning, creativity of teacher to design simple practicum, and absence of module lab. The solution to overcome these problems is to conduct simple practical training for science teachers in junior high school in Mollo Utara sub-district, South Central Timor. The method done is presentation about the nature of science, the importance of practicum in science learning, how to design of simple practical, and how to make lab module; video publisher various simple labs; and demostration of several simple practicum.
\end{abstract}

Keywords: science learnin; scientist; simple practicum

\section{PENDAHULUAN}

Memasuki abad ke-21, paradigma pembelajaran mulai mengalami perubahan dari teacher centered ke student centered dimana peserta didik dituntut untuk memiliki keterampilan berpikir tingkat tinggi. Pembelajaran pun perlu diarahkan kepada penciptaan suasana aktif, analisis, kritis dan kreatif dalam memecahkan masalah melalui pengembangan kemampuan berpikir (Depdiknas, 2006).

Salah satu ilmu yang lebih menekankan pada kemampuan berpikir tingkat tinggi adalah ilmu sains (biologi). Zubaidah (2014) mengungkapkan bahwa sains merupakan pengetahuan yang tersusun secara teratur, sistematis, universal dan berupa kumpulan data hasil pengamatan dan eksperimen. Sains pada hakikatnya terdiri atas 4 unsur yakni proses (scientific processes), produk (scientific knowledge), sikap (scientific attitude) dan teknologi. Scientific processes mengandung arti suatu aktivitas ilmiah untuk mendeskripsikan fenomena alam agar memperoleh produk sains berupa teori, fakta, konsep dan prinsip, sehingga pendekatan pembelajaran yang berorientasi pada proses sains harus melibatkan keterampilan intelektual, manual, sosial dan keterampilan proses sains (KPS)/science process skills.

Science process skills atau KPS biasanya meliputi berbagai kegiatan seperti mengamati, mengukur, mengkomunikasikan, mengklasifikasikan, bertanya, meramalkan, menyimpulkan, mengontrol variabel, merumuskan masalah, membuat hipotesis, merancang penyelidikan, dan melakukan percobaan (Nur, 2011). 
Keseluruhan kegiatan tersebut merupakan keterampilanketerampilan yang sangat cocok dengan karakteristik materi biologi.

Menurut Sudarisman (2015) materi biologi memiliki karakteristik spesifik yang berbeda dengan ilmu lainnya. Biologi banyak mengkaji tentang makhluk hidup, lingkungan maupun hubungan keduanya. Selain itu materi biologi juga tidak hanya berkaitan dengan fenomena alam yang konkret namun juga berkaitan dengan objek yang abstrak seperti metabolisme kimiawi dalam tubuh, sistem koordinasi dan hormonal. Objek kajian dalam biologi pun sangat beragam sehingga dalam merancang pembelajaran biologi diperlukan berbagai alat atau media pembelajaran dan sarana laboratorium. Meskipun demikian, masih banyak guru sains (biologi, fisika dan kimia) yang kurang memanfaatkan praktikum sebagai sarana mempelajari konsep sains, padahal kemampuan berpikir siswa dapat dikembangkan melalui kegiatan praktikum (Anwar, 2014). Praktikum merupakan salah satu cara untuk membelajarkan siswa seperti para scientist.

Implementasi praktikum IPA biologi di sekolah-sekolah terutama SMP di Kecamatan Mollo Utara Kabupaten Timor Tengah Selatan (TTS)-Nusa Tenggara Timur, saat ini masih banyak mengalami kendala. Hal ini merupakan salah satu alasan TTS dikategorikan sebagai daerah tertinggal menurut Peraturan Presiden nomor 131 tahun 2015 .

Kendala utama yang dialami oleh guru-guru IPA di beberapa SMP di Kecamatan Mollo Utara adalah karena terbatasnya sarana-prasarana laboratorium. Kondisi ini membutuhkan adanya solusi strategis terutama karena kurangnya peralatan praktikum dan kurangnya kompetensi guru dalam merancang dan menerapkan praktikum IPA. Salah satu solusi yang dapat dilakukan adalah dengan melakukan pelatihan praktikum sederhana bagi guru-guru IPA SMP Se-kecamatan Mollo Utara Kabupaten Timor Tengah Selatan.

Berdasarkan analisis situasi di atas, maka beberapa hal yang dianggap pengusul bersama mitra sebagai masalah prioritas yang harus ditangani antara lain adalah guru belum memahami hakekat pembelajaran sains, guru belum memahami pentingnya praktikum dalam pembelajaran IPA, kurangnya kreativitas guru dalam merancang praktikum IPA sederhana dan tidak adanya modul praktikum.

Tujuan kegiatan ini adalah memberikan pemahaman secara menyeluruh kepada para guru sekolah mitra khususnya guru IPA tentang hakekat pembelajaran sains, pentingnya praktikum sebagai strategi/cara yang tepat untuk mempelajari sains serta cara merancang modul praktikum IPA sederhana dan menerapkannya ke dalam pembelajaran IPA.

\section{METODE}

Kegiatan yang dilakukan untuk memecahkan permasalahan yang dialami mitra adalah pemberian materi, penayangan video praktikum sains sederhana berupa percobaan-percobaan yaitu air anti gravitasi, reaksi antara coca-cola dan kaporit, balon phobia kulit jeruk, pengendali api dengan sanitizer, tangan berasap, api antimainstream, balon antigravitasi, ilusi panah terbalik, alkohol dan air, plastik anti bocor, balon anti panas, lada dan air, kristal es, glow in the dark dan air terjun laser; dan pelatihan (demonstrasi).

Pemberian materi dilakukan dengan cara presentase menggunakan media power point dan LCD dengan materinya meliputi hakekat sains, pentingnya praktikum, cara merancang praktikum dengan bahan sederhana dan cara merancang modul praktikum dan bagaimana penerapannya dalam praktikum. Setelah pemberian materi dilanjutkan dengan penayangan video praktikum sederhana diikuti penjelasan secara singkat mengenai video yang ditayangkan. Selanjutnya diberikan pelatihan berupa demonstrasi dengan melibatkan peserta pelatihan secara langsung (gambar 1).

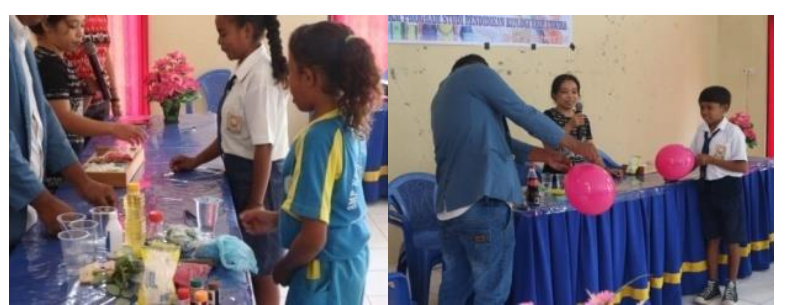

Gambar 1. Demostrasi praktikum menggunakan alat dan bahan sederhana.

\section{HASIL DAN PEMBAHASAN}

Kegiatan pengabdian kepada masyarakat ini diikuti oleh 9 orang guru dari 10 sekolah yang diundang. Selain itu, juga terdapat beberapa siswa yang juga turut hadir. Guruguru maupun para siswa sangat antusias mengikuti kegiatan ini yang ditunjukkan melalui berbagai pertanyaan yang diajukan oleh peserta. Selain itu juga terdapat beberapa masukan yang diberikan oleh guruguru serta kendala yang sering terjadi di sekolah (gambar 2).

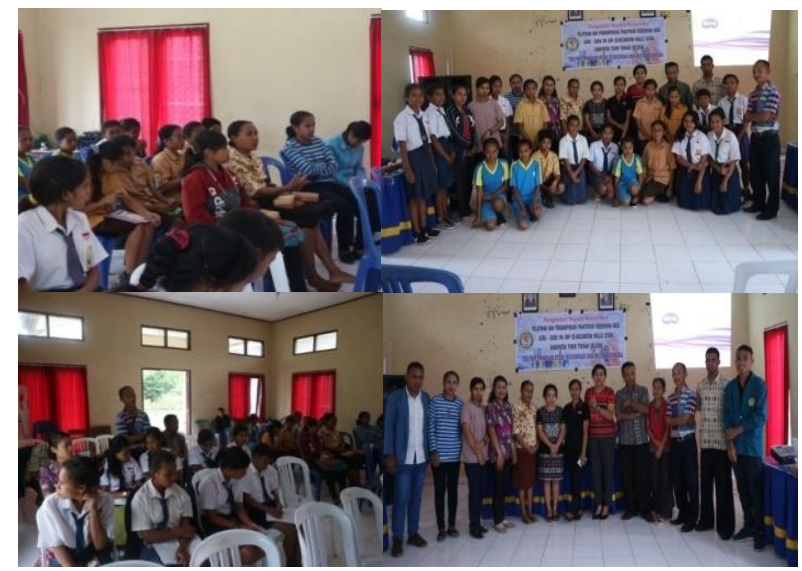

Gambar 2. Suasana pelatihan kegiatan PKM.

Hasil analisis pernyataan guru-guru yang termuat di dalam kuisioner tentang kegiatan ini disajikan dalam tabel 1, sedangkan hasil observasi oleh tim terhadap 
aktivitas guru dan siswa selama kegiatan dapat dilihat pada tabel 2 .

Tabel 1. Rekapitulasi hasil evaluasi guru-guru selama kegiatan PKM.

\begin{tabular}{clc}
\hline No & \multicolumn{1}{c}{ Aspek yang dialami } & $\begin{array}{c}\text { Ya dan } \\
\text { Setuju (\%) }\end{array}$ \\
\hline 1 & $\begin{array}{l}\text { Keikutsertaan dalam kegiatan } \\
\text { pelatihan praktikum } \\
\text { sebelumnya }\end{array}$ & 0,0 \\
2 & $\begin{array}{l}\text { Memahami hakekat } \\
\text { pembelajaran IPA }\end{array}$ \\
3 & $\begin{array}{l}\text { Memahami pentingnya } \\
\text { praktikum dalam pembelajaran }\end{array}$ & 44,4 \\
& $\begin{array}{l}\text { IPA } \\
\text { Sering melakukan percobaan }\end{array}$ \\
5 & $\begin{array}{l}\text { IPA } \\
\text { Sarana dan prasarana menjadi } \\
\text { kendala utama pelaksanaan } \\
\text { praktikum }\end{array}$ & 22,2 \\
6 & $\begin{array}{l}\text { Sering melakukan percobaan } \\
\text { dengan alat dan bahan } \\
\text { sederhana }\end{array}$ & 100,0 \\
7 & $\begin{array}{l}\text { Pelatihan IPA masih } \\
\text { diperlukan }\end{array}$ & 11,1 \\
\hline
\end{tabular}

Tabel 2. Aktivitas guru dan siswa selama kegiatan PKM.

\begin{tabular}{clcc}
\hline \multirow{2}{*}{ No } & \multirow{2}{*}{ Aspek yang diamati } & \multicolumn{2}{c}{ Keberhasilan $(\%)$} \\
Guru & Siswa \\
\hline 1 & Mendengarkan penjelasan & 100 & 100 \\
2 & $\begin{array}{l}\text { Mengajukan pertanyaan } \\
3\end{array}$ & 44,44 & 23,08 \\
& $\begin{array}{l}\text { Memberikan } \\
\text { masukan/saran } \\
\text { Terlibat dalam kegiatan } \\
\text { demonstrasi }\end{array}$ & 33,33 & 0 \\
& 100 & 100 \\
\hline
\end{tabular}

Rekapitulasi hasil evaluasi pada tabel 1 menunjukkan bahwa guru-guru IPA di Kecamatan Mollo Utara belum pernah mengikuti kegiatan pelatihan praktikum IPA sebelumnya. Hal ini menunjukkan bahwa kegiatan ini menjadi langkah yang tepat agar guru-guru IPA semakin diperkaya dengan berbagai inovasi dalam pembelajaran IPA khususnya dalam merancang percobaan-percobaan sederhana namun sarat akan materi pelajaran IPA. Pada dasarnya guru-guru IPA di Kecamatan Mollo Utara cukup memahami hakekat pembelajaran IPA dan memahami dengan baik akan pentingnya praktikum dalam pembelajaran IPA. Akan tetapi ketiadaannya sarana dan prasarana praktikum menjadi kendala utama tidak dilaksanakannya praktikum dalam pembelajaran IPA. Hal ini didukung oleh kurangnya guru-guru yang melakukan percobaan dalam pembelajaran IPA. Pemahaman guru-guru akan praktikum IPA dengan alat dan bahan sederhana juga masih sangat minim sehingga berdampak pada kurangnya inovasi guru merancang praktikum sederhana. Keseluruhan pendapat guru-guru mengenai praktikum IPA mengindikasikan bahwa pelatihan dan pendampingan praktikum IPA masih perlu dilakukan dengan lingkup yang lebih luas.
Sementara itu, hasil pengamatan pada tabel 2 menunjukkan bahwa guru dan siswa aktif mendengarkan penjelasan tentang hakekat pembelajaran IPA, pentingnya praktikum dalam pembelajaran IPA dan aktif terlibat dalam demonstrasi praktikum sederhana. Keaktifan peserta pelatihan dibuktikan dengan adanya pertanyaan dari peserta pelatihan baik guru maupun siswa, yang mana persentase guru yang bertanya adalah sebanyak 44,4\% yaitu 4 orang dari 9 peserta dan siswa sebanyak 23,08\% yaitu 2 orang dari 13 peserta. Adanya pertanyaan yang diajukan menunjukkan bahwa telah terjadi interaksi yang dinamis antara pemberi materi dan peserta pelatihan, serta menunjukkan adanya minat dan rasa ingin tahu yang tinggi dari peserta terhadap masalah/materi yang dibahas. Selain pertanyaan, peserta juga memberikan usul saran terhadap kegiatan pelatihan. Saran yang diberikan diantaranya adalah peserta pelatihan ingin adanya pelatihan serupa dengan lingkup yang lebih luas baik materi maupun khalayak sasaran terutama masyarakat sebagai salah satu stakeholder pendidikan. Hal ini dimaksudkan agar masyarakat khususnya orang tua siswa memahami dengan baik perannya sebagai salah satu sumber daya dan pemberi dukungan bagi pendidikan anak.

\section{KESIMPULAN}

Berdasarkan tujuan pelaksanaan kegiatan PKM ini maka dapat disimpulkan bahwa:

1. Guru-guru matapelajaran IPA SMP di Kecamatan Mollo Utara cukup memahami hakekat sains dan memahami dengan baik akan pentingnya praktikum dalam pembelajaran IPA.

2. Guru-guru sangat antusias mengikuti kegiatan pelatihan ini dan akan merancang modul praktikum berdasarkan pengetahuan yang telah diperoleh dalam pelatihan. Modul praktikum yang akan dirancang oleh guru-guru merupakan kelanjutan dari PKM ini pada tahun berikutnya.

\section{UCAPAN TERIMA KASIH}

Ucapan terima kasih ditujukan kepada LP2M Universitas Katolik Widya Mandira Kupang dan Camat Mollo Utara.

\section{DAFTAR PUSTAKA}

Anwar, E. D. (2014). Pelatihan Pembuatan Alat-Alat Praktikum IPA-Fisika Bagi Guru IPA SMP/Mts Swasta Se-Kecamatan Winong Kab. Pati. Jurnal Dimas, 14(1).

Depdiknas. (2006). Permendiknas No. 22 Tahun 2006 Tentang Standar Isi. Jakarta: Depdiknas.

Nur, M. (2011). Keterampilan-Keterampilan Proses Sains. Surabaya: Pusat Sains dan Matematika Sekolah Universitas Negeri Surabaya.

Sudarisman, S. (2015). Memahami Hakikat dan Karakteristik Pembelajaran Biologi Dalam Upaya Menjawab Tantangan Abad 21 serta Optimalisasi Implementasi Kurikulum 2013. Jurnal Florea, 2(1).

Zubaidah, S. (2014). Buku Guru Ilmu Pengetahuan Alam. Jakarta: Kementrian Pendidikan dan Kebudayaan. 
